\title{
Effect of Credit Sales and Accounts Receivable Control Against Operating Profit In Television Republic Indonesian (TVRI)
}

\author{
Muhammad Ryan Fahlevi ${ }^{1}$, David Ahmad Yani ${ }^{2}$ \\ \{ryanfahlevi2017@gmail.com ${ }^{1}$, davidahmadyani@ metrouniv.ac.id ${ }^{2}$ \} \\ State Islamic Institute (IAIN) Metro, Street. Ki Hajar Dewantara No.15A, Iringmulyo, East Metro \\ District., Metro City, Lampung. (34112) ${ }^{12}$
}

\begin{abstract}
This study aims to determine the effect of credit sales and accounts receivable turnover to increase operating profit. The data used are the LPP-TVRI monthly balance sheet and income statement for the years 2017-2019. The data analysis technique in this study used multiple linear regression to see the coefficients of $F, R, R^{2}$, and t. All calculations were performed using SPSS v.20. Based on test results credit sales as measured by the ratio of the amount of credit sales with the number of consumers who do credit has a positive effect on operating profit. In addition, accounts receivable control test results as measured by the ratio that measures how many times on average receivables successfully billed in one period had a positive effect on operating profit. The practical implication of this research is that the Central LPP Television of the Republic of Indonesia (TVRI) Supervisory Board should implement policies related to uncollectible accounts so as not to cause problems, such as fines imposed on late payment partners. The Supervisory Board of the Central LPP TVRI is expected to be able to implement a financial feasibility policy for consumers who will order advertising credits.
\end{abstract}

Keywords: Accounts Receivable, Credit Sales, Operating Profit, TVRI

\section{Introduction}

In many developed countries, public broadcasters such as LPP-TVRI had the full support of the state, it becomes even national identity, for example, the British Broadcasting Corporation (BBC), Radio-TV Australia $(\mathrm{ABC})$ and NHK Japan. In Indonesia, the LPP as TVRI tend to be defeated by the private broadcast agency (LPS), which has the equipment and modern technology, while LPP-TVRI still using the transmitter old, transmitter LPPTVRI spread throughout Indonesia are still using a transmitter in 1962, has not been replaced with equipment more modern.

The nation's attention to the LPP-TVRI intended as a counterweight against LPS which tend to promote the business benefits alone, in contrast with LPP-TVRI of its broadcasting provide public information and education can play a role in the development of the nation's character. As a public broadcaster that does not mean LPP-TVRI should not gain an advantage, due 
to limitations of the state budget LPP-TVRI make management work hard to seek alternative funding in order to meet the limited funds of the state budget revenues. For public broadcasting, advertising is not something that is prohibited, depending on how the public will determine how many restrictions on ad impressions per hour and advertisements which are considered appropriate for public broadcasting.

To achieve these objectives, LPP-TVRI rely on its activities in the form of advertising sales, the greater the volume the greater the advertising sales profits or revenue to be obtained by the company. In this study, of course LPPTVRI unlike the private TV station which can impose fundraising and cooperation with external parties (advertisers or investors) given TVRI is a public institution. However, limited funds are not made LPP-TVRI lagging behind in terms of programs. Many programs on the theme of education and culture as well as lift the local value packed nuances created LPP-area TVRI has a high value in the public interest the provinces of Lampung, Lampung News program call and Culinary Indonesia. Here the amount of revenue derived from advertising LPP-TVRI:

Table 1. Ads Revenue Realization LPP-TVRI

\begin{tabular}{cccccc}
\hline \multirow{2}{*}{ Year } & \multicolumn{2}{c}{ Advertising revenue (IDR) } & \multirow{2}{*}{ Total } & Target (Rp) & $\begin{array}{c}\text { percentage of } \\
\text { Achievement }\end{array}$ \\
\hline 2017 & Cash (IDR) & Credit & & & $92.22 \%$ \\
2018 & 117.200 .000 & 297.800 .000 & 415.000 .000 & 450.000 .000 & $94.14 \%$ \\
2019 & 112.972 .800 & 357.747 .200 & 470.720 .000 & 500.000 .000 & $84.02 \%$ \\
\hline Source: LPP-TVRI, 2019 & 319.264 .256 & 420.084 .547 & 500.000 .000 &
\end{tabular}

Based on the table, it appears that advertising revenue TVRI has yet to reach the expected target, even tended to decrease from the previous year, this was due to lack of promotion and dissemination to the public and business partners-LPP TVRI. Advertising sales on credit policy implemented by the LPP-TVRI cause receivables it is because there is a grace period between when broadcasting advertising until receipt of money that need / will take approximately 6 months. If the repayment of non-current receivables, especially receivables with a time period of more than one year it will disrupt the financial position, especially the cash flow position, because a lot of working capital tied up in the form of accounts. The following receivables conditions in LPP-TVRI during the years 2017-2019. 
Table 2. Ads Credit Sales LPP-TVRI

\begin{tabular}{cccccc}
\hline \multirow{2}{*}{ Year } & Total Receivables & \multicolumn{2}{c}{ Receivables (Rp) } & \multicolumn{2}{c}{ Receivables (\%) } \\
& $(\mathrm{Rp})$ & collectible & doubtful & collectible & doubtful \\
\hline 2017 & 400.512 .000 & 297.800 .000 & 102.712 .000 & $74.35 \%$ & $25.65 \%$ \\
2018 & 509.021 .552 & 357.747 .200 & 151.274 .352 & $70.28 \%$ & $29.72 \%$ \\
2019 & 429.319 .058 & 319.264 .256 & 110.054 .802 & $74.37 \%$ & $25.63 \%$ \\
\hline Source LPP-TVRI 2019 & & & &
\end{tabular}

Source: LPP-TVRI, 2019

Based on Table 1.2 looks total receivables LPP-TVRI in 2019 amounted to 429319058 , that figure is receivables doubtful partly in a period of 10-12 months, it causes bad debts which will have an impact on receivables.

Business Organization in their attempts to make profit adopt several strategies and one of which is allowing credit to customers [1]. [2] Submitted that credit is a marketing tool for expanding sales. Sales made on credit to customers must be considered carefully because if there is no effort to regulate sales on credit, there may be problems especially those related to liquidity. and company cash flow.

Based on existing theories, that under normal circumstances when higher credit sales, the profit that will be obtained will be high as well and accounts receivable turnover is high then the opportunity to earn large profits also will be high. Thus, the turnover of receivables and credit sales has been duly contributed positively to the net profit of the company so that the survival and progress of the company can be predicted.

The company's credit sales policy will refer to the actions taken to provide, monitor, and collect cash as accounts receivable [3]. A typical organizational credit policy contains four variables: a collection policy, a cash discount policy, the credit period extended and the standard of credit sales. [4] Classifies it as a credit limit, based on credit terms, time deposits, customer information and documentation of a sale. All components of a company's credit policy can be used as a tool to monitor receivables as a result of credit sales. All activities include all types of customers

In the sales system in LPP-TVRI has a variety of obstacles, in particular on credit sales system. Advertising sales on credit in the LPP-TVRI experiencing a bottleneck among others, the delay in the payments made by consumers, this has led to profits from the company less than the maximum so the impact on the activity of LPP-TVRI. The following receivables conditions in LPP-TVRI during the years 2017-2019: 
Table 3. Total receivables LPP-TVRI

\begin{tabular}{cccccc}
\hline & & \multicolumn{4}{c}{ future Receivables } \\
Year & amount & $0-6$ months & $7-9$ months & $10-12$ months & $>12$ months \\
\hline 2017 & 102712000 & $41,444,292$ & $25,472,576$ & $16,125,784$ & $19,669,348$ \\
2018 & 151274352 & $46,895,049$ & $66,560,715$ & $15,732,533$ & $22,086,055$ \\
2019 & 110054802 & $41,050,441$ & $38,629,236$ & $15,187,563$ & $15,187,563$ \\
\hline \multicolumn{2}{l}{ Source: LPP-TVRI, 2019}
\end{tabular}

Based on Table 3 looks total receivables LPP-TVRI in 2019 amounted to 110054802 , and most have a time deadline to pay more than 6 months, it causes bad debts which will have an impact on receivables. Accounts receivable management is a critical element in the survival of a business, because the receivables are financial resources or cash one of the benefits is to finance the company's operations.

\section{Framework}

Receivables arise because companies do credit sales to increase its business volume. [5] States declared receivable turnover indicates the dependent period working capital in accounts where the faster the revolving period showed the larger the company benefit from the sale of the credit. So that the company's profit also increased.

[6] Revealed that, "when credit sales are effectively managed profitability is at a desirable level. The finding revealed that when a firm's debitors turnover is favorable, liquidity is at a desirable level". [7] Have seen that "most companies after granting credit sales rely on them as assets without providing adequately for possible. bad and doubtful debts. With this situation, the financial statements of such companies obviously will lack true and fair view because of the fact that the amount of trade debtors cannot be fully realized". Research work has shown that "credit sales enhance both profitability and liquidity positions of firms if properly managed".

Credit sales and accounts receivable turnover will benefit the company because it more attractive to prospective buyers so that the sales volume increase which means to increase revenues or profits. On the other hand sales on credit often creates kerugiaan, ie if the debtor is unwilling or unable to perform its obligations. These losses in accounting known as share names, such as accounts receivable losses, the cost of bad debts and doubtful accounts expense. 
The decision on credit policy is a trade-off between the benefits gained from increased sales and the costs of approving credit. Based on the appropriate analysis of reports, controlling should help the management to bring such business decisions aimed towards customers and to take all the necessary measures for obeying the appropriate legal regulations. This way, controlling may influence better liquidity of a company, which includes faster cash turnover, payment to its suppliers, lower outstanding accounts, and better profitability. Apart from the general importance of controlling credit sales and collection of receivables [8].

In order to reduce and minimize credit sales risk, the sales company uses the controlling of credit sales and receivables. Controlling holds a special position in planning and supervision of credits sales but also in developing standards used in the realization of such a process [9].

Receivables are the component of every company's assets. They are the result of numerous factors with the most important one being our decision to sell our goods or services with the belief that customers will pay them in the future. This is precisely the characteristic by which they are just like any other form of assets that organizations and employees invest in [10]. Every company that provides deferred payment or credit sales needs to have a clearly defined plan of collection of its receivables [11].

The company must be able to measure the average number of days in a year it takes the company to collect its receivables and convert it into cash. If the collection period exceeds the company's credit term, it may be a signal that the company is inefficient in collecting revenue from credit sales or approving credit to margin customers [12].

The company's goal conduct credit sales, which are to increase sales turnover and other purposes from credit sales is the accounts receivable turnover the company to the customer, but sales on credit is also risky for sellers is when the customer or the buyer does not pay, then the loss is called a loss of receivables, In accounting, accounts receivable losses due to nonbillable recorded by debiting accounts receivable losses. Such losses in the business world is considered as normal and the risk is appropriate for companies that do credit sales. Viewed from the standpoint of management, the loss of receivables in a reasonable amount indicates that the credit policy set by the Company are correct, loss amounts are too low to give a hint that the company's credit development policy is too tight, otherwise the loss of receivables that are too high may mean that the company's credit policy is too loose. Based on the description above frameworks can be described as follows: 


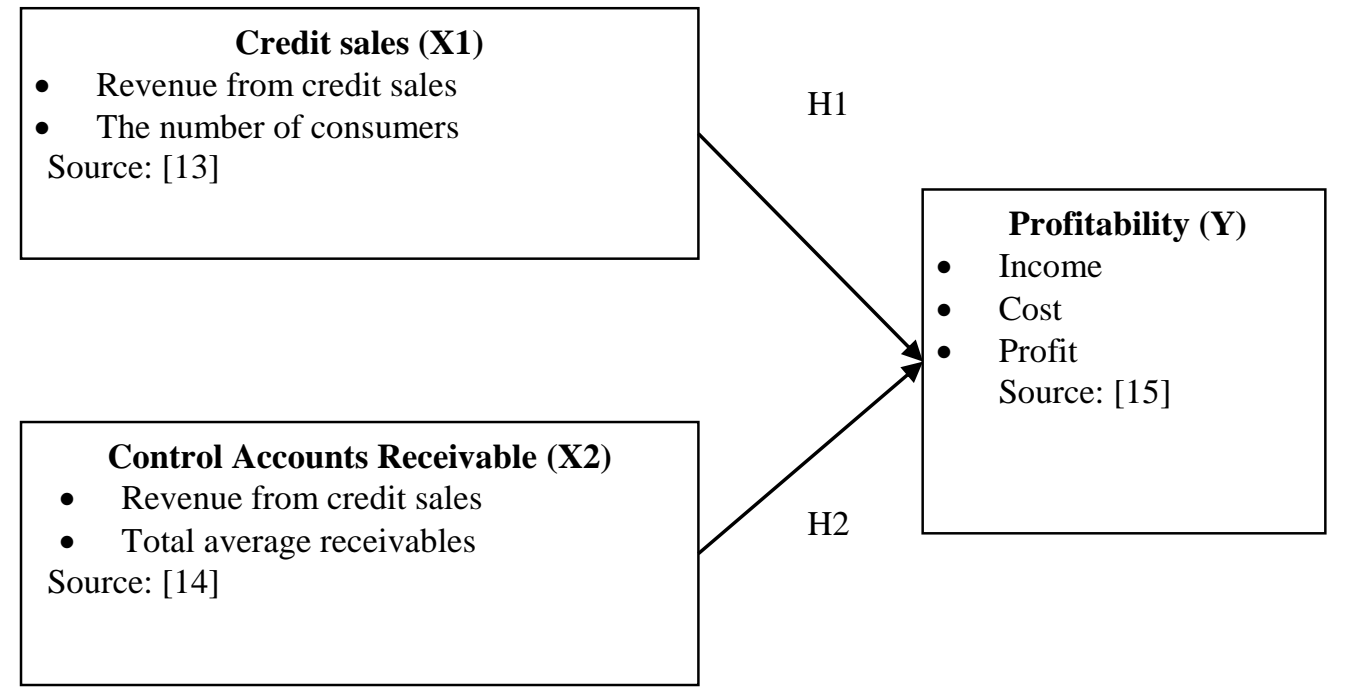

\subsection{Hypotheses}

Theoretically, credit sales as measured by the ratio of the number of credit sales to the number of consumers who do kiredt have a positive effect on operating profit. The more credit sales, the higher the operating profit. Conversely, the less credit sales, the lower the company's organizational profit. This conceptual framework produces the first hypothesis $\left(\mathrm{H}_{\mathrm{a} 1}\right)$ : Sales were affected positively credit against operating profit.

Accounts Receivable Control also has a positive effect on operating income. Accounts receivable control is measured by a ratio comparing the number of times the average receivables collected in one period have a positive effect on operating income. The better the accounts receivable multiplication, the higher the company's operating profit, and conversely, the worse the accounts receivable control, the lower the operating profit. This conceptual framework produces the second hypothesis $\left(\mathrm{H}_{\mathrm{a} 2}\right)$ : accounts receivable turnover positive effect on operating profit.

\section{$3 \quad$ Research Methods}

In this study, data analysis method used is quantitative analysis (in scale numbers) by multiple regression analysis, multiple regression method (multiple regression) made to the model proposed by the researchers used SPSS software to predict the relationship between the dependent and independent variables. Based on the formulation of the problem and the 
theoretical framework that has been described previously, the research model is formed as follows:

$$
\mathbf{N P M}=\alpha+\beta 1 P K+\beta 2 P P+e
$$

Information :

$\begin{array}{ll}\alpha & : \text { Constant coefficient } \\ \beta & : \text { Variable coefficient } \\ \text { PK } & : \text { Credit sales } \\ \text { PP } & : \text { Control Accounts } \\ \text { NPM } & : \text { Net Profit Margin } \\ \text { e } & : \text { Error term }\end{array}$

\section{$4 \quad$ Results And Discussion}

\subsection{Test Coefficient of Determination}

The value of the correlation coefficient (R2) shows how much of a correlation or relationship between independent variables with the dependent variable. The correlation coefficient $\mathrm{R}$ is said to be strong if the value is above 0.5 and close to 1 . The coefficient of determination (R2) essentially measures how far the model's ability to explain variations in the dependent variable. R2 value is zero through one. If the value of $\mathrm{R} 2$ is getting close to one, then the independent variables give all the information needed to predict the variation of the dependent variable [16].

Table 4. Testing the coefficient of determination (R2 Test)

\begin{tabular}{cccc}
\hline Model & $R$ & $R 2$ \\
\hline & 1 & 0460 & 0312 \\
\hline
\end{tabular}

Source: processed data, 2019

The testing results obtained $\mathrm{R} 2$ values of 0.312 which means a $31.2 \%$ operating profit variable-TVRI LPP can be explained by the variable Credit Sales (X1) and control Accounts (X2), while the remaining $68.8 \%$ is explained by other factors not tested in the research.

\subsection{Feasibility Model}

Here are the results of testing the feasibility of the model with the $\mathrm{F}$ statistic in the study, the test is one-way with a level of significant at 0.05 and 
the total sample of 86 involving three parameters namely first and second constant coefficients.

Table 5. Test Statistic F

ANOVA

\begin{tabular}{|ll|r|r|r|r|r|}
\hline Model & & \multicolumn{1}{|c|}{$\begin{array}{c}\text { Sum of } \\
\text { Squares }\end{array}$} & \multicolumn{1}{c|}{ df } & Mean Square & F & Sig. \\
\hline 1 & Regression &, 222 & 2 &, 111 & 5,434 &, $002^{\mathrm{a}}$ \\
& Residual &, 827 & 33 &, 025 & & \\
& Total & 1,049 & 35 & & & \\
\hline
\end{tabular}

a. Predictors: (Constant), X2, X1

b. Dependent Variable: $Y$

From these test results in table 4.8 can be seen in the significant value of 0.002 less than 0.05 , in addition to the value $F$ account 5.434 greater than $F$ table 3,23 (Appendix 3). Based on the significance level, then this model can be used to predict operating profit the LPP-TVRI. Thus, the model equations are fit or fit for use.

\section{Test Statistic t}

Table 6. Hypothesis Test Results

Coefficients ${ }^{a}$

\begin{tabular}{|ll|r|r|r|r|r|}
\hline \multirow{2}{*}{ Model } & \multicolumn{2}{|c|}{$\begin{array}{c}\text { Unstandardized } \\
\text { Coefficients }\end{array}$} & $\begin{array}{c}\text { Standardized } \\
\text { Coefficients }\end{array}$ & & \\
\cline { 3 - 5 } & & \multicolumn{1}{|c|}{ B } & Std. Error & \multicolumn{1}{|c|}{ Beta } & t & \multicolumn{1}{c|}{ Sig. } \\
\hline 1 & (Constant) & 7,174 & 3,949 & & 3,817 &, 078 \\
& X1 & 1,120 &, 652 &, 380 & 2,119 &, 035 \\
& X2 &, 019 &, 041 &, 104 & 1,869 &, 042 \\
\hline
\end{tabular}

a. Dependent Variable: $Y$

Based on the above table can be created multiple linear regression equation as follows:

$\mathrm{Y}=7.174+1,120 \mathrm{X} 1+0,019 \mathrm{X} 2$

From a regression model that is formed is then obtained by the relationship between each of the independent variables, Credit Sales (X1) and Accounts Receivable Control (X2) with the dependent variable operating profit of LPP-TVRI with significance as follows. First, marked positive constant value of 7.174 states that if there is no activity of all the two independent variables that. Affect the operating profit, the operating profit was positive. Second, the regression coefficient receivable control (X2) is 
positive, amounting to 0.019 states that the variable control of accounts receivable (X2) as measured by the ratio that measures how many times on average receivables successfully billed in one period had a positive effect on operating profit, as well as having significant value $(0,042)$ is smaller than 0.05 so that the hypothesis "receivables turnover positive effect on operating profit", is supported. Third, the regression coefficient sale of Credit (X1) is positive, amounting to 1,120 stated that the sales variable Credit (X1) as measured by the ratio of the amount of credit sales with the number of consumers who do credit has a positive effect on operating profit, as well as having significant value $(0.035)$ is smaller of 0.05 so that the hypothesis "credit Sales were affected positively to the operating profit", is supported.

\section{Discussion}

\subsection{Credit sales to operating profit}

Based on test results credit sales as measured by the ratio of the amount of credit sales with the number of consumers who do credit has a positive effect on operating profit, as measured by the ratio of net profit margin (net profit margin), this result has meaning that the higher the credit sales made by LPP TVRI it will increase the company's net profit.

The research proves that profit was positively affected by the sale of loans, this agrees with the theory that if a high credit sales, the profit that will be obtained will be higher as well. Thus, it is proper credit sales contributed positively to the net profit of the company so that the survival and progress of the company can be predicted. Credit sales may affect earnings positively because LPP TVRI have various requirements to prospective advertisers who want to make a purchase on credit, namely (a) has a deposit in the form of advances, (b) the down payment, (c) Has identity clear and (d) the presence of the prescribed time limit, so the financial risk of credit sales can be minimized.

\subsection{Receivable Turnover on operating profit}

Based on test results accounts receivable control as measured by the ratio that measures how many times on average receivables successfully billed in one period had a positive effect on operating profit, as measured by the ratio of net profit margin (net profit margin), therefore, the second hypothesis which states that " accounts receivable turnover positive effect on operating profit "is received, this result has meaning that the higher trade receivables due to the sale of advertisement on credit, it will increase business profits. 
Receivables are recognized after the MOU was made by LPP TVRI and approved by the advertiser. For advertisers who have registered the recognition of receivables related to the recognition of revenue on LPP TVRI initiated when the customer makes a booking ads to the sales department and has been signed by the supervisor of sales and on the basis of the memo that agreement from the credit department, and issued a letter through to the section editor for ad serving, then submitted to the administration to do media creation order. The order media as evidence began the process of credit sales which give rise to receivables for the company.

Smoothness receivables and better measurement of investments in receivables can be seen from the level of turnover. Turnover period of receivables are receivables of an enterprise during a certain period. Receivables contained in the company will always be rotating. Accounts receivable turnover will show how many times the receivables arising until such receivables are collectible transferred back to the company. Accounts receivable turnover rate can be used as an illustration of the effectiveness of management of accounts receivable due to the higher level of accounts receivable turnover of a company means the better management of receivables.

The problems that often arise in the LPP TVRI that the delay in the payments made by the partners, there is even a partner under payments, if may someday happen doubtful accounts, for example, one of the partners is declared bankrupt or is unable to meet its obligations in paying off its debts to LPP LPP TVRI TVRI then to report accounts with direct elimination method. For that before LPP TVRI decided to conduct credit sales, the prior calculation of the amount of funds invested in accounts receivable, sales and payment terms are desirable, possible loss of receivables (bad debts) and the costs that will arise in the handling of receivables.

\section{Conclusion}

Based on test results credit sales as measured by the ratio of the amount of credit sales with the number of consumers who do credit has a positive effect on operating profit, therefore, it is in line with the initial hypothesis proposed the author of "Selling credit positive effect on operating profit". Based on test results receivable control as measured by the ratio that measures how many times on average receivables successfully billed in one period had a positive effect on operating profit, in line hypothesis "Receivables turnover positive effect on operating profit". 


\section{Implication}

This result suggested to the Supervisory Board of LPP TVRI Center in order to implement policies related to doubtful accounts so as not to cause receivables, as the fines imposed on the partners who are late to pay, because it is based on existing theories, that under normal circumstances when credit sales high profits that will be obtained will be high as well and accounts receivable turnover is high then the opportunity to earn large profits also will be high. Thus, the turnover of receivables and credit sales has been duly contributed positively to the net profit of the company.

It is also recommended to the Supervisory Board of LPP TVRI Center in order to implement a policy of financial feasibility to consumers who will book credit advertising.

This study only uses NPM to assess the company's profit. For further research is expected to develop this study to assess other financial ratios that can be used to assess the performance of the company such as earnings or ROE, and ROI.

\section{ACKNOWLEDGMENTS}

Our thanks to State Islamic Institute (IAIN) Metro, who have supported this research, and all parties who helped this research to completion, including to ACM SIGCHI for allowing us to modify templates they had developed. 


\section{References}

[1] Ifurueze, M.S.K. 2013. The Impact of Effective Management of Credit Sales on Profitability and Liquidity of Food and Beverage Industries in Nigeria. Global Journal of Management and Business Research. 13(2) 112-130

[2] Pandey, I.M. (2004): Financial Management, 9th Ed. New-Delhi India; Vikas Publishing House PVT Ltd

[3] Maysami R. C. 2010. "Understanding and Controlling Cash flow" Financial Management series. Retrieved November 12, 2010. From: www.sciencedirct.com

[4] Miller C. 2008. "Is it time to review your credit policy". Retrieved November 20, 2010. From www.cr ditresearchfoundationonline.com

[5] Mulyadi. 2010. Accounting System, 3rd Edition, 5th Printing. Publisher Salemba Four, Jakarta.

[6] Ifurueze, M.S.K. 2013. The Impact of Effective Management of Credit Sales on Profitability and Liquidity of Food and Beverage Industries in Nigeria. Global Journal of Management and Business Research. 13(2) 112-130

[7] Beckan, T.N and Richard, E. B (1984): Credit and collection management and Theory, 8th Ed. New York, Mcgraw Hill Book Coy

[8] Kozarevic, E., Delic, A., Omerovic, M. 2019. The Role of Controlling credit Sales and Receivables in the Wood Processing Companies of Tuzla Canton, Bosnia and Herzegovina, International Journal of Industrial Engineering anf Management 10(1): 933-103

[9] Polić, N., Kozarević, E., Džafić, J. (2016), Finansijski kontroling, The University of Zenica,Zenica.

[10] Khan, M. Y., Jain, P. K., (2008), Financial Management, McGraw-Hill, New Delhi.

[11] Andersson, S., Bergman, T. (2009), "Controlling Corruption in the Public Sector", Scandinavian Political Studies, Vol.32, No. 1, pp. 45-70

[12] Belak, V. (2014), Analiza poslovneus pješnosti, RRiF, Zagreb.

[13] Maysami R. C. 2010. "Understanding and Controlling Cash flow" Financial Management series. Retrieved November 12, 2010. From: www.sciencedirct.com

[14] Kasmir. 2016 Financial Statement Analysis. Jakarta: King Grafindo Persada.

[15] Harahap, Sofyan Syafri. 2015. Critical Analysis of the Financial Statements. 1-10 edition. Jakarta: Rajawali Pers.

[16] Ghozali, Imam.2013. Multivariate Aplikasi Analysis dengan IBM SPSS 21. Program Diponegoro University, Semarang 